\title{
DIE BEPERKINGS VAN REGSTELLENDE GELYKHEID
}

F Venter

Noordwes-Universiteit (Potchefstroom Kampus)

\section{Inleiding}

Die Suid-Afrikaanse samelewing vertoon skrikwekkende ongelykhede tussen individue en (veral rasse-)groeperinge. ${ }^{1}$ Hierdie situasie is uit die sosiale, ekonomiese, morele en juridiese perspektiewe 'n kernprobleem, wat ook verklaar waarom dit so prominent in die Grondwet en wetgewing figureer.

Sedert 1994 het gelykheid heelwat politieke, parlementêre, regterlike en akademiese aandag ontvang, maar dit is geen oordrywing om te sê dat die Suid-Afrikaanse gelykheidsreg nog in sy kinderskoene staan nie.

In hierdie bydrae word 'n kompakte oorsig gegee van die stand van die gelykheidsreg, veral met die oog daarop om die beklemtoning van wat regstellende gelykheid genoem word, te beoordeel. Uit die ontleding blyk dit dat die gelykheidsreg bepaalde wanbalanse vertoon wat moeilik met die bepalings van die Grondwet ${ }^{2}$ versoen kan word. Om tekortkominge in die gelykheidsreg, wat te goeder trou bedoel is om die brandende probleme van ongelykheid op te los, uit te wys, kan in die huidige tydsgewrig maklik verkeerd verstaan word as reaksionêre weerstand teen 'n noodsaaklike proses van 'n geregverdigede gelykheidstrewe. Dit is egter hoegenaamd nie waaroor dit hier gaan nie. Dit gaan wel daaroor dat die gelykheidstrewe met behulp van die reg gebalanseerd nagejaag moet word ten einde te verseker dat die grense van gelykheid self nie oorskry word nie, aangesien dit teen die wese van gelykheid as waarde sal indruis.

\section{Gelykheid in die Grondwet}

Die begrip "gelykheid" kom in die hoogsverskanste stigtingsbepaling van die 1996 Grondwet (artikel 1), verskeie kere in die Handves van Regte en verder slegs in artikels 185

1 Die bronne wat Dupper 2002 SA Merc LJ 280-281 aanhaal, voorsien 'n bondige, maar duidelike beeld van hierdie ongelykhede.

2 Grondwet van die Republiek van Suid-Afrika, 1996. 
en 187 in verband met twee grondwetlike kommissies ${ }^{3}$ voor.

Die Handves se gelykheidsbepaling, dit wil sê artikel 9 waarvan "Gelykheid" die opskrif is, bevat die mees spesifieke hantering van die gelykheidsbegrip in subartikels (1) en (2):

(1) Elkeen is gelyk voor die reg en het die reg op gelyke beskerming en voordeel van die reg.

(2) Gelykheid sluit die volle en gelyke genieting van alle regte en vryhede in. Ten einde die bereiking van gelykheid te bevorder, kan wetgewende en ander maatreëls getref word wat ontwerp is vir die beskerming of ontwikkeling van persone, of kategorieë persone, wat deur onbillike diskriminasie benadeel is.

Subartikels (3)-(5) handel met die teenhanger van gelyke behandeling, naamlik diskriminasie. Subartikel (3) verbied onbillike diskriminasie deur die staat, subartikel (4) verbied onbillike diskriminasie deur enige persoon en subartikel (5) skep die vermoede dat diskriminasie op enige van die gronde wat in subartikel (3) gespesifiseer word, onbillik is.

Subartikel (2) kan beskryf word as die belangrikste bepaling wat "regstellende aksie" veroorloof. Die regstellende aksiesentiment word egter gerugsteun deur die tweede sin van subartikel (4), ingevolge waarvan nasionale wetgewing verorden moet word om onbillike diskriminasie te voorkom of te belet, asook deur artikel 217(2) wat die staat magtig om 'n verkrygingsbeleid te volg waardeur persone of kategorieë persone wat deur onbillike diskriminasie benadeel is, te beskerm of te bevorder en deur artikel 146(2)(c)(v), wat "die bevordering van gelyke geleenthede of gelyke toegang tot regeringsdienste" tot een van die maatstawwe vir die voorrang van nasionale wetgewing bo konkurrente provinsiale wetgewing verhef.

Die Grondwet skep dus nie 'n "reg op gelykheid" nie, maar hanteer die gelykheidsbegrip deurgaans as 'n waarde. ${ }^{4}$ In artikel 1(a) word bepaal dat die Suid-Afrikaanse staat "gegrond

3 Die Kommissie vir die Bevordering en Beskerming van die Regte van Kultuur-, Godsdiens- en Taalgemeenskappe en die Kommissie vir Geslagsgelykheid. 
is" op bepaalde waardes, waarvan die tweede wat genoem word "die bereiking van gelykheid" is. In artikel 7(1) (die eerste bepaling van die Handves van Regte) word bepaal dat die Handves onder meer die "demokratiese waarde van gelykheid" bevestig. Dat die Grondwet nie met 'n reg op gelykheid, of 'n "reg om gelyk te wees" werk nie, val nie vreemd op nie, aangesien dit voor die hand lê dat dit nie realisties moontlik is om iets wat onbestaanbaar is, te skep nie. Ongelykheid is 'n natuurlike gegewe, wat nie ongedaan gemaak kan word deur die skepping van 'n regsaanspraak om nie ongelyk te wees nie. Wat wel moontlik is, en wat inderdaad deur artikel 9(1) van die Grondwet gedoen word, is om 'n reg te skep op gelyke beskerming en voordeel van die reg en bepaalde konkrete, konteksbepaalde regte kan ook afgelei word uit die eerste frase van die subartikel wat die stelling grondwetlik bevestig dat elkeen gelyk is voor die reg.

\section{Gelykheid in die regspraak}

Die voorganger van artikel 9 van die 1996 Grondwet was artikel 8 van die 1993 Grondwet, wat nie in alle opsigte met eersgenoemde ooreengekom het nie. 'n Belangrike volume regspraak het egter uit die vertolking en toepassing van artikel 8 voortgespruit, ${ }^{5}$ wat deur die Konstitusionele Hof as volledig van toepassing op die huidige artikel 9 aanvaar is. ${ }^{6}$

$4 \quad$ In die hantering van die gelykheidsbegrip in die regspraak en die literatuur word maklik gepraat van 'n "reg op gelykheid", terwyl die Grondwet nie so 'n reg skep nie. Tipies van so 'n onversigtige omgang met die terminologie is die sleutel-dictum perO'Regan $r$ in Dawood v Minister of Home Affairs 20003 SA 936 (KH) par [35]: "This Court has already acknowledged the importance of the constitutional value of dignity in interpreting rights such as the right to equality, the right not to be punished in a cruel, inhuman or degrading way, and the right to life. Human dignity is also a constitutional value that is of central significance in the limitations analysis. Section 10, however, makes it plain that dignity is not only a value fundamental to our Constitution, it is a justiciable and enforceable right that must be respected and protected. In many cases, however, where the value of human dignity is offended, the primary constitutional breach occasioned may be of a more specific right such as the right to bodily integrity, the right to equality or the right not to be subjected to slavery, servitude or forced labour." (onderstreping bygevoeg). Dupper 2002 SA Merc LJ praat ook in die aangehaalde artikel sonder meer met verwysing na a 8 van die 1993 Grondwet en a 9 van die 1996 Grondwet van "the constitutional right to equality." 'n Interessante (en meer aanvaarbare) benadering is om, soortgelyk aan Cowen, van "gelykheidsregte" in die Grondwet te praat (Cowen 2001 SAJHR 34 praat van "the equality right").

5 Brink $v$ Kitshoff 19964 SA $197(\mathrm{KH})$, Prinsloo $v$ Van der Linde 19973 SA $1012(\mathrm{KH})$, President of the Republic of South Africa v Hugo 19974 SA 1 (KH), Harksen v Lane 19981 SA $300(\mathrm{KH})$, Larbi-Odam v MEC for Education (North West Province) 19981 SA 745 (KH) en Pretoria City Council v Walker 19982 SA $363(\mathrm{KH})$.

6 Par [15] van die uitspraak perAckermann $\mathrm{r}$ in National Coalition for Gay and Lesbian Equality $v$ Minister of Justice 19991 SA 6 (KH). 
'n Kompakte uiteensetting van die gestruktureerde vertolkingsproses by die toepassing van die gelykheidsbepaling is in paragraaf [53] van die Harksen-uitspraak geyk, en ten opsigte van die huidige artikel 9 in par [17] van die Gay and Lesbian-uitspraak herbevestig en effens in die daaropvolgende paragraaf [18] verfyn. Dit kom neer op drie hoofstappe, elk met bepaalde substappe. Die hoofstappe kan as die beantwoording van die volgende drie vrae (in volgorde) opgesom word:

(a) Differensieer die gewraakte handeling tussen mense of kategorieë mense?

(b) Indien wel, kom sodanige differensiasie neer op onbillike diskriminasie?

(c) As die teenwoordigheid van onbillike diskriminasie vasgestel is, kan die gewraakte handeling ingevolge die beperkingsbepaling (artikel 36) geregverdig word?

Hierdie riglyne geniet weens die vanselfsprekende belangrikheid daarvan en die kompleksiteit verbonde aan die toepassing daarvan op konkrete situasies heelwat aandag en dit is duidelik dat daar nog baie ontwikkelingswerk daaraan gedoen sal moet word. ${ }^{7}$ Rautenbach se analises, ${ }^{8}$ kommentaar en kritiek op die Harksen-riglyne demonstreer die kompleksiteit van die saak en wys ook duidelik hoedat verskillende beklemtonings moontlik is. Hy argumenteer byvoorbeeld dat die onderskeid tussen diskriminasie en onbillike diskriminasie in die tweede stap verwarrend en onnodig is, ${ }^{9}$ onder meer omdat die optrede wat in artikel 9(1) verbied word, 'n afdoende reëling tref sodat "diskriminasie" nie as derde kategorie gewraakte optrede in die Grondwet ingelees hoef te word nie. ${ }^{10}$

Van meet af aan het die Konstitusionele Hof, in navolging van die Kanadese regspraak, 'n regstreekse verband tussen gelykheid en menswaardigheid getrek. ${ }^{11}$ Hierdie benadering is

$7 \quad$ Verdere ontwikkeling van die riglyne is egter nie die fokus van hierdie artikel nie. Vgl bv die analises van Rautenbach 2001 TSAR 329 (en sy vorige analise van 1998 waarna verwys word) asook die reeks van vier artikels van Carpenter 2001 THRHR 409; 2001THRHR 619; 2002 THRHR 37 en 2002 THRHR 177.

8 Rautenbach 2001 TSAR 329.

9 Rautenbach 2001 TSAR 334-335.

10 Waarskynlik is die rede vir die invoer deur die Hof van die onderskeid tussen diskriminasie en onbillike diskriminasie te vinde in die bewoording van a 9(5) van die Grondwet.

11 "The prohibition on unfair discrimination in the interim Constitution seeks not only to avoid discrimination against people who are members of disadvantaged groups. It seeks more than that. At the heart of the prohibition of unfair discrimination lies a recognition that the purpose of our new constitutional and democratic order is the establishment of a society in which all human beings will be accorded equal dignity and respect regardless of their membership of particular groups. The achievement of such a society in the context of our deeply inegalitarian past will not be easy, but that that is the goal of the Constitution should not be forgotten or overlooked." Goldstone $\mathrm{r}$ in President of the Republic of South Africa v Hugo 1997 (4) SA 1 (KH) par [41]. 
nie sonder omstredenheid nie, en het redelike skerp kritiek in die literatuur ontlok. ${ }^{12}$ Ten spyte van die omstredenheid kan daar nietemin min twyfel daaroor bestaan dat die heersende leer oor hierdie punt daarop berus dat die kernwaarde waarop die Grondwet gefundeer is, menswaardigheid is, en dat dit bepalend is vir die wyse waarop gelykheidsregte vertolk en toegepas word. ${ }^{13}$

\section{Wat beteken "gelykheid"?}

"Gelykheid" is geen eenvoudige begrip met 'n eenduidige betekenis nie en dit word in die Suid-Afrikaanse regspraak baie pertinent in die Suid-Afrikaanse konteks, veral die historiese konteks, vertolk. ${ }^{14}$ Anders as in die Amerikaanse gelykheidsregspraak, waar 'n formele gelykheidsbegrip die toon aangee, word substantiewe gelykheid in Suid-Afrika nagestreef. Ockert Dupper ${ }^{15}$ verduidelik die verskil soos volg:

In short, formal equality means sameness of treatment - the law must treat persons in the same manner regardless of their circumstances. Substantive equality takes the circumstances of people into account and requires the law to ensure equality of outcome. The Constitution, it is then stressed, requires us to look at substance. It requires us to focus on the purpose or effects of rules and conduct and not merely on their form.

Die Konstitusionele Hof het die Suid-Afrikaanse gelykheidskonsep tot dusver as "regstellende of herstellende gelykheid" getipeer. ${ }^{16}$ Daardeur is 'n betekenis aan gelykheid

12 Cowen 2001 SAJHR 51 behandel hierdie debat en neem self die standpunt in dat "The use of dignity as a concept can ... serve to encourage, rather than hinder, a substantive equality analysis because it permits, and arguably requires, thought to be given to structural and economic factors underlying material disadvantage and economic power relations."

13 'n Insiggewende dictum in hierdie verband is ook dié van Sachs $\mathrm{r}$ in par [124] van die Gay and Lesbian-uitspraak: "Contrary to the Centre's argument, the violation of dignity and self-worth under the equality provisions can be distinguished from a violation of dignity under section 10 of the Bill of Rights. The former is based on the impact that the measure has on a person because of membership of an historically vulnerable group that is identified and subjected to disadvantage by virtue of certain closely held personal characteristics of its members; it is the inequality of treatment that leads to and is proved by the indignity. The violation of dignity under section 10 , on the other hand, contemplates a much wider range of situations. It offers protection to persons in their multiple identities and capacities. This could be to individuals being disrespectfully treated, such as somebody being stopped at a roadblock. It also could be to members of groups subject to systemic disadvantage, such as farm workers in certain areas, or prisoners in certain prisons, such groups not being identified because of closely held characteristics, but because of the situation they find themselves in. These would be cases of indignity of treatment leading to inequality, rather than of inequality relating to closely held group characteristics producing indignity."

14 Vgl die nuttige samevatting deur Swanepoel "Equality Jurisprudence" 186-187.

15 Dupper 2002 SA Merc LJ 221, n 4.

16 "Remedial or restitutionary equality", by monde van Ackermann $\mathrm{r}$ in National Coalition for Gay and Lesbian Equality v Minister of Justice 19991 SA 6 (KH) par [60] en [61]. 
gekoppel wat optrede veronderstel. Dit strook met die formulering in artikel 1 van die Grondwet wat die bereiking van gelykheid as een van die waardes waarop die Republiek van Suid-Afrika gebou is, identifiseer, en ook met artikel 9(2) wat owerheidsmaatreëls magtig waardeur die bereiking van gelykheid bevorder word. Die veronderstelling van optrede spreek egter nie so duidelik uit artikel 7(1), waar gelykheid as sodanig as een van die "demokratiese waardes" beskryf word, of uit artikel 9(1), wat handel oor die reg op gelyke beskerming en voordeel van die reg nie. Verder vind 'n mens in artikels 36(1) en 39(1) vermelding van gelykheid as deel van die beskrywing van 'n gemeenskap, naamlik een wat gebaseer is op (onder meer) gelykheid.

Artikel 9(2) se eerste sin is die enigste bepaling wat spesifieke betekenisinhoud aan die begrip gee: gelykheid sluit naamlik "die volle en gelyke genieting van alle regte en vryhede in." Hierdie beskrywing van gelykheid is toepasbaar op al drie die gemelde konsepte wat met gelykheid verbind word ('n waarde, regte en 'n beskrywing). Die betekenis wat die Grondwet dus aan "gelykheid" toeken,

- is die strewe daarna dat almal alle regte en vryhede ten volle en gelyk moet geniet;

- maak die volle en gelyke genieting van alle regte en vryhede die toets daarvoor of 'n persoon gelyk is voor die reg en of die reg op gelyke beskerming en voordeel van die reg gerespekteer word en

- bring mee dat die soort gemeenskap wat in artikels 36 en 39 beskryf word, een is waarin almal alle regte en vryhede ten volle en gelyk geniet.

Gelykheid, nie net as filosofiese konstruksie of as morele maatstaf nie, maar ook as grondwetlike en regskonsep, is ryk en veelfasettig. Dit is gevolglik nie 'n begrip wat hom daartoe leen om eensydig verstaan en toegepas te word nie, aangesien die teenoorgestelde van gelykheid daardeur bewerkstellig kan word. Die grens tussen gelykheid en ongelykheid is baie skerp en die mobilisering van gelykheid vir die bereiking van politieke, ideologiese of pragmatiese oogmerke kan dus geredelik tot ongelykheid en onreg lei.

\section{Gelykheidswetgewing}

Die mees prominente stukke implementeringswetgewing rakende gelykheid is die Wet op Billike Indiensneming 55 van 1998 en die Wet op die Bevordering van Gelykheid en die 
Voorkoming van Onbillike Diskriminasie 4 van 2000. Eersgenoemde wet het hoofsaaklik op arbeidsregtelike verhoudinge betrekking, terwyl laasgenoemde 'n meer algemene toepassing het.

\subsection{Die Wet op Billike Indiensneming, 1998}

Artikel 2 van hierdie Wet bepaal: ${ }^{17}$

The purpose of this Act is to achieve equity in the workplace by-

(a) promoting equal opportunity and fair treatment in employment through the elimination of unfair discrimination; and

(b) implementing affirmative action measures to redress the disadvantages in employment experienced by designated groups, in order to ensure their equitable representation in all occupational categories and levels in the workforce.

Hoofstuk II van die Wet verbied onbillike diskriminasie in enige indiensnemingsbeleid of praktyk teen enige werknemer op een of meer gronde, en spesifiek op enige van die gronde wat in artikel 9(3) van die Grondwet gelys word, asook gesinsverantwoordelikheid, MIV status en politieke standpunte, en is van toepassing op alle werkgewers en werknemers.

Ingevolge artikel 6 is die neem van regstellende aksiestappe enersyds, en andersyds die onderskeiding, uitsluiting van of voorkeur vir enige persoon op grond van 'n inherente vereiste van 'n pos, nie onbillike diskriminasie nie.

Hoofstuk III, onder die opskrif "Affimative Action", is van toepassing op aangewese werkgewers, wat gedefinieer word as iemand wat 50 of meer werknemers het, minder as 50

17 Daar is nie 'n Afrikaanse weergawe van die teks nie. Die voorrede lui soos volg: Recognising-

- that as a result of apartheid and other discriminatory laws and practices, there are disparities in employment, occupation and income within the national labour market; and

- that those disparities create such pronounced disadvantages for certain categories of people that they cannot be redressed simply by repealing discriminatory laws,

Therefore, in order to-

- promote the constitutional right of equality and the exercise of true democracy;

- eliminate unfair discrimination in employment;

- ensure the implementation of employment equity to redress the effects of discrimination;

- achieve a diverse workforce broadly representative of our people;

- promote economic development and efficiency in the workforce; and

- give effect to the obligations of the Republic as a member of the International Labour Organisation, ... 
werknemers het maar ' $n$ jaarlikse omset bo 'n bedrag tussen twee en vyf en twintig miljoen rand afhangende van die sektor, munisipaliteite, staatsorgane (met enkele uitsonderings) en werkgewers wat in 'n kollektiewe arbeidsooreenkoms as aangewese werkgewer geïdentifiseer is.

Artikel 15 beskryf regstellende aksie-maatreëls in subartikel (1) as "measures designed to ensure that suitably qualified people from designated groups have equal employment opportunities and are equitably represented in all occupational categories and levels in the workforce of a designated employer." Regstellende aksie-maatreëls moet ingevolge subartikel (2)(d) onder meer maatreëls insluit om "equitable representation of suitably qualified people from designated groups in all occupational categories and levels in the workforce" te verseker en om mense uit die aangewese groepe in diens te neem en te ontwikkel. Subartikel (3) bepaal dan:

(3) The measures referred to in subsection (2)(d) include preferential treatment and numerical goals, but exclude quotas.

'n Werkgewer wat nie aan die bepalings van die Wet voldoen nie, word ingevolge artikel 53 nie toegelaat om enige kontrak vir dienslewering of voorsiening aan 'n staatsorgaan te sluit nie en die Arbeidshof kan boetes van tot R900,000 oplê vir die nie-nakoming van die bepalings van die Wet.

\subsection{Die Wet op die Bevordering van Gelykheid en die Voorkoming van Onbillike}

\section{Diskriminasie, 2000}

Hierdie $\mathrm{Wet}^{18}$ is aangeneem om uitvoering te gee aan die vereistes van artikel 9 van die Grondwet. ${ }^{19}$ Hoewel dit reeds in Februarie 2000 gepromulgeer is, het die belangrikste bepalings van die Wet op 16 Junie 2003 in werking getree omdat 'n proses van opleiding van hofpersoneel vir gelykheidshowe eers van stapel gestuur moes word, ${ }^{20}$ regulasies

18 Die teks daarvan is nie in Afrikaans gepromulgeer nie. In die gewysigde a 31(2)(b) is dit egter aan die Minister opgedra om die teks in al die amptelike tale beskikbaar te maak binne twee jaar nadat die Wet in werking getree het.

19 Vgl die lang titel, die voorrede en a 2 van die Wet.

20 A 31(4). 
uitgevaardig moes word ${ }^{21}$ en 'n Gelykheidshersieningskomitee ("Equality Review Committee") tot stand gebring moes word. ${ }^{22}$

Soos dit uit die titel van die Wet blyk, word twee oogmerke daardeur nagestreef, naamlik die voorkoming van (veral) onbillike diskriminasie, ${ }^{23}$ en die bevordering van gelykheid. ${ }^{24}$

Hoofstuk 2 bevat artikels 6 tot 12. Artikel 6 herhaal die essensie van subartikels (3) en (4) van artikel 9 van die Grondwet deur onbillike diskriminasie deur die staat of deur enigeen teen enige persoon te verbied. Artikel 7 verbied onbillike diskriminasie op grond van ras en beskryf ' $n$ vyftal kategorieë van spesifieke vorms van sodanige diskriminasie. Hierdie patroon word herhaal in artikel 8 aangaande geslagsdiskriminasie en artikel 9 wat oor diskriminasie op grond van gestremdheid handel. Artikel 10 verbied haatspraak (en voorsien besonderhede oor die aard van haatspraak), artikel 11 verbied teistering ("harassment") en artikel 12 verbied die publikasie van inligting waardeur onbillike diskriminasie in die hand gewerk word.

Die bepalings van hoofstuk 3 van die Wet maak voorsiening vir stappe en oorwegings by die vasstelling van die billikheid of onbillikheid van diskriminasie, terwyl hoofstuk 4 regsprekende meganismes (sogenaamde gelykheidshowe) daarstel om met die beregting van onbillike diskriminasie te handel.

Die tweede hoofoogmerk van die Wet, naamlik die bevordering van gelykheid, kom in Hoofstuk 5 aan die orde. 'n Plig om gelykheid te bevorder, word in artikels 24 tot 27 aan die staat, alle persone en instellings opgelê en in artikel 28 word "spesiale maatreëls" getref om gelykheid op grond van ras, geslag en gestremdheid te bevorder. Artikel 29 skep, met verwysing na die Bylae tot die Wet, 'n "illustratiewe lys" onbillike handelinge met die oog daarop om praktyke wat onbillik is, of onbillik mag wees, te illustreer en te beklemtoon.

Die Wet word in artikel 5(2) beklee met 'n hoër status as ander wetgewing. Die bepaling maak daarvoor voorsiening dat, indien enige strydigheid tussen die Wet en die bepalings van enige ander wet in verband met 'n aangeleentheid waaroor die Wet handel, sou ontstaan,

21 A 30

22 A 32-33. Die Komitee is op 1 September 2000 aangestel (GK R874 in SK 21517 van 1 September 2000), maar die Portefeuljekomitee vir Justisie en Grondwetlike Ontwikkeling het op 25 September 2002 twyfel uitgespreek oor die bekostigbaarheid en sin van die voortbestaan van die Komitee, aangesien "Parliament already fulfils an oversight function."

23 Veral Hfst 2 van die Wet word hieraan gewy.

24 Hfst 5 van die Wet word hieraan gewy. 
die bepalings van die Wet voorrang moet geniet. Die enigste uitsonderings wat toegelaat word, is die Grondwet en 'n parlementswet wat die Wet uitdruklik wysig. ${ }^{25}$

In aansluiting by artikel 9 van die Grondwet word daar in die teks van die Wet deurgaans gebruik gemaak van die meganisme van verbode gronde vir diskriminasie. In artikel 1(1) word "verbode gronde" eerstens in 'n subparagraaf (a) gedefinieer as presies dieselfde gronde wat in artikel 9(3) van die Grondwet voorkom, en dan word die volgende as alternatief ("or") bygevoeg:

(b) enige ander grond waar diskriminasie wat op sodanige ander grond gebaseer is -

(i) sistemiese benadeling veroorsaak of voortsit;

(ii) menswaardigheid ondermyn, of

(iii) die gelyke genieting van 'n persoon se regte op 'n ernstige manier wat vergelykbaar is met diskriminasie op een van die gespesifiseerde gronde, nadelig raak.

Dit is duidelik dat hierdie toevoeging deur die Konstitusionele Hof se regspraak geïnspireer is. Die feit dat paragraaf (b) in die definisie volg op "or", dui daarop dat dit bedoel word as 'n aanvulling van die lys gronde wat in artikel 9(3) van die Grondwet voorsien word. Anders gestel, indien diskriminasie voorkom op 'n ander grond as een van dié wat in artikel 9(3) van die Grondwet gelys word, ag die Wet dit so goed as gelys indien dit die uitwerking het wat in subparagraaf b) beskryf word. Die bepaling is natuurlik die verwoording van stap (b)(i) van die Harksen-toets, ${ }^{26}$ waarin daar egter nie melding gemaak word van "sistemiese benadeling" nie. Die presiese betekenis van "sistemiese benadeling" kan nie geredelik uit die Wet vasgestel word nie, aangesien geen definisie daarvan voorsien word nie. Hoogs waarskynlik is die begrip ingevoer om uitdrukking te gee aan 'n dictum van Goldstone $r$ in par [51] van die Harksen-uitspraak waar melding gemaak word van "patterns of disadvantage" uit die verlede. ${ }^{27}$ Die

25 Hierdie meganisme van die verlening aan buite-grondwetlike wetgewing van hoër status as ander reg kom elders in die post-konstitusionele statutêre reg ook, bv a 70 van die Wet op Hoër Onderwys 101 van 1997.

26 "Firstly, does the differentiation amount to 'discrimination'? If it is on a specified ground, then discrimination will have been established. If it is not on a specified ground, then whether or not there is discrimination will depend upon whether, objectively, the ground is based on attributes and characteristics which have the potential to impair the fundamental human dignity of persons as human beings or to affect them adversely in a comparably serious manner." (par [54] van die Harksen-uitspraak).

27 "In order to determine whether the discriminatory provision has impacted on complainants unfairly, 
uitdrukking "sistemiese benadeling" het egter wel al 'n paar keer in die Konstitusionele Hof se uitsprake voorgekom. ${ }^{28}$

\subsection{Statutêre voortbouing op die grondwetlike bepalings oor gelykheid}

Die bogemelde twee wette is gepromulgeer met die spesifieke doel om uitvoering te gee aan die tweede sin van artikel 9(2) van die Grondwet. Die wette gaan egter soos volg verder as artikel 9:

Die Wet op Billike Indiensneming, 1998

- Artikel 6(1) voeg drie spesifieke gronde waarop nie onbillik teen 'n werknemer gediskrimineer mag word nie by die lys van die Grondwet, naamlik gesinsverantwoordelikheid, MIV status en politieke standpunte.

- Artikel 6(2) sluit twee potensieel teenoorstellende optredes eksplisiet uit van die betekenis van onbillike diskriminasie: eerstens regstellende aksie_maatreëls wat in ooreenstemming met die doel van die Wet geneem word, en tweedens onderskeiding, uitsluiting en voorkeur van enige persoon weens 'n inherente vereiste van 'n werk.

- Artikel 15(3) laat voorkeurbehandeling en die stel van numeriese doelwitte toe by die neem van regstellende aksie-maatreëls waardeur mense uit die aangewese groepe bevoordeel word.

various factors must be considered. These would include:

(a) the position of the complainants in society and whether they have suffered in the past from patterns of disadvantage, whether the discrimination in the case under consideration is on a specified ground or not; ..." (par [51] van die Harksen-uitspraak).

28 Miskien bevat die volgende dictum uit par [91] van die Gauteng Education Bill-uitspraak, (1996 3 SA $165(\mathrm{KH})$ ) per Sachs $\mathrm{r}$ die duidelikste aanduiding (onderstreping bygevoeg): "Exactly how the correct balance should be struck between the importance of overcoming systemic inequality inherited from the past, on the one hand, and preventing legally enforced or de facto assimilation of groups wishing to preserve and develop a distinctive identity, on the other, would, in my view, be primarily a matter for democratic resolution in the legislatures of our country, and not in the first instance be one of adjudication by the courts." Vgl ook Sachs r se dictum in par [124] van die Gay and Lesbian-uitspraak wat hierbo in n 13 weergegee is. 
Die Wet op die Bevordering van Gelykheid en Voorkoming van Diskriminasie, 2000

- Artikels 7, 8 en 9 spesifiseer spesifieke vorms van onbillike diskriminasie op grond van onderskeidelik ras, geslag en gestremdheid.

- Artikels 10 en 12 bou voort op die grondwetlike bepaling (artikel 16) oor vryheid van uitdrukking deur onderskeidelik haatspraak wat betrekking het op die gedefinieerde verbode gronde nader te omskryf en diskriminerende verspreiding van inligting met bepaalde kwalifikasies te omlyn.

- Artikel 1(1)(xxii)(a) herhaal die lys van gronde waarop onbillike diskriminasie verbied word soos dit in artikel 9(3) van die Grondwet voorkom. Artikel 34(1) van die Wet maak voorsiening vir uitbreiding van hierdie lys deur die Minister. Meer daaroor hieronder.

- Die bepalings van hoofstuk 3 van die Wet maak voorsiening vir stappe en oorwegings by die vasstelling van die billikheid of onbillikheid van diskriminasie.

- Artikel 29 skep, met verwysing na die Bylae tot die Wet, 'n "illustratiewe lys" onbillike handelinge met die oog daarop om praktyke wat onbillik is of onbillik mag wees te illustreer en te beklemtoon.

\subsection{Houdbaarheid van die statutêre uitbreidings}

Die jong Grondwet-gestuurde gelykheidsreg is in Suid-Afrika ongekarteerde gebied. Die Grondwet gaan daarvan uit dat die historiese (veral rasse-)diskriminasie waarvoor SuidAfrika in die tweede helfte van die twintigste eeu berug was, beëindig en omgekeer moet word. $^{29}$ Die gelykheidstrewe word dikwels as die sentrale tema van die Grondwet

29 Per slot van rekening lui die openingswoorde van die voorrede van die Grondwet: "Ons, die mense van Suid-Afrika, erken die ongeregtighede van ons verlede ..." 
aangemerk..$^{30}$ Die post-grondwetlike Parlement fokus skerp op regstelling van onregte en wanbalanse. Daar kan gevolglik verwag word dat wetgewing,owerheidsoptrede en selfs die howe in hierdie verband die grondwetlike grense in belang van regstelling sal toets. Op die lange duur moet die gelykheidsreg van 'n regstaatlike bedeling egter gebalanseerd wees en aan alle aspekte van die eise wat regverdigheid stel, voldoen. Derhalwe loon dit om die houdbaarheid van die statutêre uitbreidings op die Grondwetlike reëlings onder die loep te neem.

\subsubsection{Regstellende aksie}

Artikel 9(2) van die Grondwet se tweede sin veroorloof regstellende aksie "ten einde die bereiking van gelykheid te bevorder", dit wil sê om die grondwetlike waarde waarvan artikel 1 melding maak, te verwesenlik. Wetgewende en ander maatreëls wat ontwerp is vir die beskerming of ontwikkeling van persone wat deur onbillike diskriminasie benadeel is, moet dus primêr betrekking hê op die bereiking van gelykheid as waarde. ${ }^{31}$

Die frase in die Engelse teks van die Grondwet ${ }^{32}$ wat as magtiging vir regstellende aksie dien, lui: "measures designed to protect or advance persons, or categories of persons, disadvantaged by unfair discrimination." Hierdie formulering bied nie 'n waterdigte identifiseringsmaatstaf waarvolgens bepaal kan word wie voordeel moet trek uit die beskermende en bevorderende maatreëls nie. 'n Letterlike uitleg van die frase dui daarop dat dit hier gaan oor persone of kategorieë persone teen wie daar daadwerklike, dit wil sê aanwysbare, onbillike diskriminasie gepleeg is. 'n Meer begunstigende uitleg, wat moontlik ook as doeldienend, en (met verwysing na gelykheid as grondwetlike waarde) teleologies,

30 Vgl bv die dictum van Mahomed r in S v Makwanyane 1995 (3) SA 391 (KH); 1995 (6) BCLR 665 par [262]: "In some countries, the Constitution only formalizes, in a legal instrument, a historical consensus of values and aspirations evolved incrementally from a stable and unbroken past to accommodate the needs of the future. The South African Constitution is different: it retains from the past only what is defensible and represents a decisive break from, and a ringing rejection of, that part of the past which is disgracefully racist, authoritarian, insular, and repressive and a vigorous identification of and commitment to a democratic, universalistic, caring and aspirationally egalitarian ethos, expressly articulated in the Constitution." Vgl verder Davis 1999 SALJ 400-401: "The concept of equality lies at the centre of the South African constitutional idea."

31 Vgl McGregor 2002 SA Merc LJ 253 by n5 en die skrywers daar aangehaal: "Affirmative action measures can be defended only by showing that the measures promote the achievement of equality and are designed to protect and advance persons disadvantaged by unfair discrimination." 'n Paar sinne vroeër skryf sy egter: "The Constitution sees affirmative action as part of the right to equality..." wat egter nie korrek kan wees nie. Gelykheid as grondwetlike waarde en die gelykheidsregte moet van mekaar onderskei word. Per slot van rekening skryf McGregor net op die volgende bladsy dat daar nie op regstellende aksie gesteun kan word om 'n werknemer te verplig om 'n iemand aan te stel nie, maar dat dit slegs as verweer teen 'n bewering van onbillike diskriminasie kan dien. 
beskryf kan word, sou 'n betekenis van die frase kon oplewer waardeur aanwysbare diskriminasie nie vereis word nie. In so 'n geval kan dit as voldoende geag word dat 'n persoon een van 'n klas is waarteen die voorgrondwetlike regstelsel onbillik gediskrimineer het. Dit is moontlik wat die Konstitusionele Hof met die frase systemic inequality inherited from the past bedoel het ${ }^{33}$ en hoe die uitdrukking verstaan moet word waar dit in die wetgewing voorkom.

Die probleem met die ruimer uitleg is egter dat die grondwetlike magtiging van regstellende maatreëls op sigself nie ongekwalifiseerd is nie. Die konteks waarin die magtiging in artikel 9(2) van die Grondwet geskep word, is die nadere presisering van gelykheid as (onder meer) "die volle en gelyke genieting van alle regte en vryhede", gevolg deur die oogmerk wat die maatreëls moet nastreef, naamlik die bevordering van die bereiking van gelykheid. Die spesiale maatreëls wat geoorloof word, het dus 'n beperkte doel, wat ook beskryf sou kon word as die bekamping van die ongelyke genieting van alle regte en vryhede veroorsaak deur onbillike diskriminasie. Die bepaling magtig dus die bevoordeling van mense, maar veroorloof nie benadeling of diskriminasie nie. Anders gestel, indien 'n regstellende maatreël die bereiking van gelykheid op 'n manier bevorder waardeur onbillik gediskrimineer word, kan dit nie grondwetlik geregverdig word nie.

Die doel van die Wet op Billike Indiensneming 1998, soos uiteengesit in artikel 2 (hierbo weergegee), strook met die bostaande vertolking van artikel 9(2) van die Grondwet deurdat daarmee beoog word om gelyke geleenthede en billike behandeling in indiensneming te bevorder deur die eliminering van onbillike diskriminasie en die implementering van regstellende aksie-maatreëls om benadeling van die aangewese groepe in indiensnemingspraktyke uit te skakel. Waar 'n werknemer minder gunstig as 'n ander werknemer deur 'n werkgewer behandel word, bied die regstellende aksie-konsep volgens die huidige stand van die regspraak 'n verweer, dit wil sê 'n regverdigingsgrond, aan die werkgewer teen die bewering van onbillike diskriminasie. ${ }^{34}$

A 9(2) en vgl ook a 217(2)(b).

Punt 5.2 hierbo.

McGregor 2002 SA Merc LJ 254: "It appears that affirmative action can be a defence to direct and indirect discrimination. It is important to note that only affirmative action measures consistent with the purpose of the Employment Equity Act - to ensure the equitable representation of designated groups in all occupational categories and levels in the workforce - justifies discrimination." Vgl ook Dupper 2002 SA Merec LJ 287 n85. 
Artikel 6(2) van die Wet beoog om regstellende aksie-maatreëls uit die reikwydte van die begrip "onbillike diskriminasie" te haal, maar kwalifiseer die betekenis van regstellende aksie met die woorde "affirmative action measures consistent with the purpose of this Act". Daarmee word regstellende aksie-maatreëls duidelik aan die oogmerke en beperkings van artikel 9(2) van die Grondwet gekoppel. ${ }^{35}$ Hierdie voltooide sirkel moet sonder twyfel in aanmerking geneem word by die vertolking van artikel 15(3) van die Wet, waar "preferential treatment and numerical goals" ingesluit word in die regstellende aksiemaatreëls wat 'n aangewese werkgewer moet neem. Diskriminerende voorkeurbehandeling ingevolge die Wet mag dus steeds nie onbillike diskriminasie in die hand werk nie. Die vraag wat hieruit voortvloei, is of die standpunt dat regstellende aksie 'n verweer teen onbillike diskriminasie is, verdedigbaar is. Die Grondwet laat geen onbillike diskriminasie toe nie.

Dit is verder opvallend dat artikel 14(1) van Wet 4 van 2000 die regstellende aksie-frase van die Grondwet uitbrei deur te bepaal: "It is not unfair discrimination to take measures designed to protect or advance persons or categories of persons disadvantaged by unfair discrimination or the members of such groups or categories of persons" (kursivering bygevoeg).

Die raaisel verbonde aan hierdie formulering is wat die betekenis van die bykomende verwysing na die lede van benadeelde groepe kan wees. Die byvoeging lyk toutologies, aangesien die bevordering van 'n groep persone onvermydelik die lede van die groep ten goede kom. Indien die frase egter nie 'n betekenislose toutologie moet wees nie, kan die oogmerk daarvan wees om te verseker dat persone wat nooit aan aanwysbare persoonlike diskriminasie onderworpe was nie, maar wat deel is van 'n groep of kategorie mense teen wie in die verlede onbillik gediskrimineer is, nogtans die voordeel van regstellende maatreëls kan geniet. Daar kan met stelligheid geargumenteer word dat die bevoordeling van sodanige onbenadeelde bo ander onbenadeeldes op grond van lidmaatskap van sy betrokke groep, as ongrondwetlike diskriminasie aangemerk behoort te word, aangesien die bereiking van gelykheid nie ingevolge artikel 9(2) van die Grondwet bevorder word as persone teen wie daar nie onbillik gediskrimineer is nie, beskerm word. Die enigste teenargument in so 'n geval kan wees dat die aanstelling van die onbenadeelde gedoen word om "sistemiese ongelykheid" reg te stel, of, in die taal van artikel 15(2)(d)(i) van die Wet op

35 Vgl Dupper 2002 SA Merc LJ 277-278 "...affirmative action still has to comply with the basic 
Billike Indiensneming, 1998 om "the equitable representation of suitably qualified people from designated groups in all occupational categories and levels in the workforce" te verseker. Dit is egter 'n argument wat moeilik stand kan hou teen die feit dat die Grondwet geen onbillike diskriminasie toelaat nie. Die vermelding in artikel 9(2) van die Grondwet van die "beskerming en ontwikkeling van ... kategorieë persone wat deur onbillike diskriminasie benadeel is", vereis ongetwyfeld dat sistemiese ongelykhede teengewerk moet word - daar is egter geen grondwetlike magtiging vir onbillike diskriminasie in dié proses nie.

In 'n soortgelyke sin as wat regstellende aksie nie aan persone uit die aangewese groepe enige regte verleen nie, skend geoorloofde regstellende aksie nie enige regte van 'n niebevoordeelde nie. Vir 'n gebalanseerde siening van wat hierbo "regstellende gelykheid" genoem is, moet daar dus onderskei word tussen nie-bevoordeling en regskending. Die omvang van die nie-bevoordeelde se gelykheidsregte word nie ingeperk deur die bevordering van die bereiking van gelykheid nie. Sou regstellende aksie-maatreëls so 'n uitwerking hê, sal dit ongrondwetlik wees. Die konseptuele lastigheid van "regstellende gelykheid" lê daarin dat nie-benadeeldes se gelykheidsregte soos verleen in artikel 9(1) van die Grondwet, gekwalifiseer word deur die moontlikheid dat benadeeldes onder bepaalde omstandighede voorkeurbehandeling bo hulle mag ontvang. Sulke voorkeurbehandeling moet egter binne die raamwerk van die grondwetlike waarde-ideaal van die bereiking van gelykheid plaasvind.

Dupper $^{36}$ skets drie analitiese modelle aan die hand waarvan regstellende aksie-maatreëls beoordeel kan word en wat bepaal word deur verskillende opvattings oor gelykheid. Daar is eerstens die formele of simmetriese model wat individuele regte beklemtoon en die toepassing van enige gronde om te diskrimineer, selfs in belang van benadeelde groepe, as onaanvaarbare diskriminasie hanteer (dit is die benadering in die Verenigde Koninkryk). Die benadering wat in die Europese gemeenskapsreg gevolg word, word beskryf as die "gelyke geleenthede"-benadering, wat daarvan uitgaan dat almal wat meeding, in 'n gelyke wegspringposisie geplaas moet word. Individuele belange word dus ook beklemtoon, maar regstellende stappe word as oorgangsmaatreëls toegelaat om die gevolge van strukturele diskriminasie te oorkom. Die derde model, wat volgens Dupper die Suid-Afrikaanse reg kenmerk, noem hy "substantiewe gelykheid." Hierdie model vereis die aktiewe

constitutionally infused requirements", en die gesag waarna hy daar in n 21 verwys. 
betrokkenheid van die staat om die voortsetting van diskriminasie in die gemeenskap te bekamp, dit verwerp die klem op individualisme en is uitdruklik asimmetries:

Discrimination against groups who have been historically disadvantaged is considered to be qualitatively different from discrimination aimed at remedying that disadvantage. A measure that favours relatively disadvantaged groups at the expense of those who are relatively well of is not discriminatory, since the consequence of such a measure is, in the end, a more equal society. ${ }^{37}$

Hierdie model veronderstel dus inderdaad die regverdiging van "omgekeerde diskriminasie". ${ }^{38}$

Die modelle wat Dupper voorhou, is insiggewend en bruikbaar, maar kan nie as die enigste, of selfs deurslaggewende, maatstaf vir die vertolking van die gelykheidsreg aanvaar word nie. Die vraag is nie wat die heersende ideologie agter regstellende aksie-maatreëls is, wat 'n mens se voorkeursiening oor gelykheid is, of watter analitiese model gebruik word nie, maar wat regtens, en meer spesifiek, grondwetlik regverdigbaar is. 'n Analitiese model kan nie gebruik word om die betekenis van artikel 9 van die Grondwet wesenlik te verander nie.

\subsubsection{Eksemplariese vorms van diskriminasie}

Op soortgelyke wyse as die Wet op Billike Indiensneming 1998, is die geformuleerde oogmerke van die Wet op die Bevordering van Gelykheid en Voorkoming van Diskriminasie 2000, soos in artikel 2 uiteengesit, noukeurig op die bepalings van die Grondwet afgestem. Subparagraaf 2(b) stel dit byvoorbeeld duidelik dat die doel is "to give effect to the letter and spirit of the Constitution". Die vertolkingsriglyne vervat in artikel 3(1)(a) van die Wet vereis onnodig (aangesien die Grondwet by die vertolking van alle regsreëls voorrang geniet) dat daar aan die bepalings van die Grondwet uitvoering gegee moet word, en dan in subparagraaf (b) ook aan die voorrede, doelstellings en beginselriglyne van die Wet, "thereby fulfilling the spirit, purport and objects of the Act." Laasgenoemde riglyn veroorloof natuurlik nie die toepassing van die Wet op enige wyse wat nie volkome versoenbaar is met die Grondwet nie. Dieselfde geld ook die beginselriglyne van die Wet vervat in artikel 4, waaronder subartikel (2):

Dupper 2002 SA Merc LJ 278 ev.

Dupper 2002 SA Merc LJ 280.

38 Die Arbeidshof het inderdaad ook die begrip "reverse discrimination" by ten minste een geleentheid gebruik in Ntai v SA Breweries (2001) 22 ILJ 214 (AH) op 218-219. 
(2) In the application of this Act the following should be recognised and taken into account:

(a) The existence of systemic discrimination and inequalities, particularly in respect of race, gender and disability in all spheres of life as a result of past and present unfair discrimination, brought about by colonialism, the apartheid system and patriarchy; and

(b) the need to take measures at all levels to eliminate such discrimination and inequalities.

Die belangrike oorweging in hierdie verband is natuurlik nie dat die wetgewing beperkend uitgelê moet word ten einde die impak daarvan (idealiter die bereiking van gelykheid) te verminder nie. Inteendeel, die Grondwet vereis, soos aangetoon, aktiewe optrede waardeur die bereiking van gelykheid bevorder moet word. Weens die meer gedetailleerde inhoud van die Wet, kan die Grondwet egter in die gewone gang van sake maklik na die agtergrond verskuif word, waardeur die fout begaan kan word om aan die spesifieke wetsbepalings, sommiges waarvan heelwat vaaghede bevat, ${ }^{39}$ hoër status te verleen as wat regtens geoorloof is.

In hierdie konteks is dit ook nodig om die status te oorweeg van die "illustratiewe lys onbillike praktyke" van artikel 29 en die Bylae van die Wet. In subartikel (1) word aangedui dat die lys se doel is om bepaalde praktyke te illustreer en te beklemtoon "which are or may be unfair," en subartikel (4) bepaal dat die lys daargestel word sodat die praktyke aangespreek en ge-elimineer kan word en om persone behulpsaam te wees om hulle ervarings en praktyke te vertolk. Subartikel (2) plaas 'n verpligting op die staat om stappe te neem om die gelyste praktyke (wat ingevolge subartikels (3) en (5) nie 'n numerus clausus is nie) aan te spreek ("address"). Die lys self is onder tien hoofde georden ${ }^{40}$ en bevat verskeie items wat besonder vaag en algemeen is of wat bewys van subjektiewe motiewe vereis. ${ }^{41}$

39 Vgl bv a 7(b)-(d).

40 Arbeid en indiensneming; onderwys; gesondheidsdienste en -voordele; behuising, akkommodasie, grond en eiendom; versekeringsdienste; pensioene; vennootskappe; professies en liggame; voorsiening van goedere, dienste en fasiliteite en klubs, sport en verenigings.

41 Voorbeelde is: "The failure to reasonbly and practicably accommodate diversity in education", "Failing to reasonbly accommodate the special needs of the elderly", "Determining in an unfair discriminatory manner who should be invited to become a partner in the partnership in question" en "Failure to promote diversity in selection of representative teams." 
Indien die vertolker en toepasser van hierdie Wet die toepaslike grondwetlike bepalings, en veral die duidelike, maar ook beperkende grondwetlike oogmerk van die bevordering van die bereiking van gelykheid uit die oog verloor, bestaan die gevaar dat die gelykheidsreg eksemplaries en vervolgend toegepas sal word, in plaas van konstruktief en prinsipieel soos die Grondwet vereis.

\subsubsection{Uitbreiding van die lys van verbode diskriminasiegronde}

Soos hierbo reeds uitgewys, bevat artikel 6(1) van die Wet op Billike Indiensneming, 1998 'n weerkaatsing van die lys van spesifieke gronde waarop ingevolge artikel 9(3) van die Grondwet nie onbillik gediskrimineer mag word nie, maar weef drie verdere gronde in, naamlik gesinsverantwoordelikheid, MIV-status en politieke standpunte. In artikel 11 word die bewyslas om die billikheid van beweerde onbillike diskriminasie aan te toon op die werkgewer op soortgelyke wyse as artikel 9(5) van die Grondwet, geplaas. Die vermoede dat diskriminasie wat op enige van die grondwetlik-gelyste gronde plaasvind, onbillik is, word dus in die indiensnemingskonteks uitgebrei na die drie bykomende gronde.

Artikel 34(1) van die Wet op die Bevordering van Gelykheid en die Verbod op Diskriminasie 2000, lui soos volg:

(1) In view of the overwhelming evidence of the importance, impact on society and link to systemic disadvantage and discrimination on the grounds of HIV/AIDS status, socio-economic status, nationality, family responsibility and family status-

(c) special consideration must be given to the inclusion of these grounds in paragraph (a) of the definition of "prohibited grounds" by the Minister;

(d) the Equality Review Committee must, within one year, investigate and make the necessary recommendations to the Minister.

Artikel 34(2)(c) sluit hierby aan:

(2) Nothing in this section -

(c) prevents a court from making a determination that any of these grounds are grounds in terms of paragraph (b) of the definition of "prohibited grounds" 
or are included within one or more of the grounds listed in paragraph (a) of the definition of "prohibited grounds".

Die taak van die Gelykheidhersieningskomitee (of waarskynlik uiteindelik die betrokke parlementêre portefeuljekomitee) is onder meer om die Minister oor die werking van die Wet te adviseer en om gereëld verslag aan die Minister te doen waarin aanbevelings gemaak word oor moontlike wysigings aan die Wet om die werking daarvan te verbeter. ${ }^{42}$ Hieruit blyk dit dus dat 34(1)(a) op die oog het dat die metode vir die byvoeging van die vyf bykomende gronde van diskriminasie die wysiging van die Wet, en nie van die Grondwet nie, is.

Ten einde die implikasies hiervan deeglik te verstaan, moet die wyse waarop artikel 9 van die Grondwet met die saak handel, in ag geneem word. Die krag van eksplisiete vermelding van spesifieke gronde vir verbode diskriminasie is geleë in die bewyskrag wat daarin opgesluit is. Hierdie funksie word in artikel 9(5) van die Grondwet geskep:

Diskriminasie op een of meer van die gronde in subartikel (3) vermeld, is onbillik, tensy daar vasgestel word dat die diskriminasie billik is.

Hierdie grondwetlike reëling kan beskryf word as die skepping van 'n vermoede, naamlik dat, as diskriminasie op een van die gelyste gronde plaasvind, sodanige diskriminasie onbillik is, tensy die teendeel bewys word. Hierdie vermoede het baie konkrete neerslag gevind in die driestap-vertolkingsmetode wat deur die howe ontwikkel is. Nadat daar in die eerste vertolkingstap in 'n gegewe geval vasgestel is dat differensiasie plaasgevind het, moet daar in die tweede stap bepaal word of die differensiasie neerkom op onbillike diskriminasie. Daarvoor moet twee sake beoordeel word, naamlik: ${ }^{43}$

(a) kom die differensiasie neer op diskriminasie? As daar wel differensiasie is, en die differensiasie vind op een van die gespesifiseerde gronde plaas, stel dit diskriminasie daar. As die differensiasie egter nie op een van die gronde wat in artikel 9(3) gespesifiseer word, gepleeg is nie, sal die vraag of die differensiasie inderdaad diskriminasie is, van die objektiewe vraag afhang of die grond waarop die differensiasie plaasgevind het, te doen het met eienskappe wat die potensiaal het om die betrokkenes se fundamentele

42 A 33(1)

43 Bv par [17] van die Gay and Lesbian-saak. 
menswaardigheid aan te tas, of om hulle op 'n vergelykbaar ernstige wyse nadelig te raak;

(b) wanneer daar nou op hierdie wyse vasgestel is dat die differensiasie op diskriminasie neerkom, moet vasgestel word of dit onbillike diskriminasie is. As die diskriminasie op een van die gespesifiseerde gronde gepleeg is, word onbillikheid veronderstel. Waar die diskriminasie op 'n nie-gespesifiseerde grond gepleeg is, is die bewyslas op die klaer om die onbillikheid daarvan te bewys.

Dit blyk baie duidelik hieruit dat die tweede gedeelte van die definisie in artikel 1(1)(xxii) van die Wet op die Bevordering van Gelykheid en die Verbod op Diskriminasie, 2000 van "verbode gronde" statutêre uitdrukking wil gee aan die maatstawwe vir die beoordeling van die onbillikheid van diskriminasie op nie-gespesifiseerde gronde soos wat dit in die regspraak ontwikkel is. ${ }^{44}$ Artikel 34(1) van die Wet het dit egter oor die gespesifiseerde gronde wat in die eerste deel van die definisie uit die Grondwet oorgeskryf is: dit is hierdie lys wat oënskynlik uitbreibaar gemaak word deur wetswysiging.

Die grondwetlike houdbaarheid van die gestelde statutêre oogmerk om die gespesifiseerde gronde van artikel 9 van die Grondwet langs die weg van wetswysiging uit te brei, lyk prima facie verdag. Sou die Minister iewers in die toekoms 'n wysiging van die Wet se definisie van "verbode gronde" in die Parlement ter tafel lê, moet die vraag onmiddellik ontstaan of dit geoorloof is om bepalings van die verhewe Grondwet op hierdie wyse uit te brei. Die probleem kan gedmonstreer word aan die hand van 'n geval waar 'n persoon onbillike diskriminasie op grond van sy MIV-status ingevolge die Wet op Billike

44 A 13 van die Wet, wat oor bewyslas handel, en a 14, wat oor die bepaling van billikheid en onbillikheid handel neem dit ' $n$ stap verder. A 13 bepaal:

13 Burden of proof

(1) If the complainant makes out a prima facie case of discrimination-

(a) the respondent must prove, on the facts before the court, that the discrimination did not take place as alleged; or

(b) the respondent must prove that the conduct is not based on one or more of the prohibited grounds.

(2) If the discrimination did take place-

(a) on a ground in paragraph (a) of the definition of 'prohibited grounds', then it is unfair, unless the respondent proves that the discrimination is fair;

(b) on a ground in paragraph (b) of the definition of 'prohibited grounds', then it is unfair-

(i) if one or more of the conditions set out in paragraph (b) of the definition of 'prohibited grounds' is established; and

(ii) unless the respondent proves that the discrimination is fair. 
Indiensneming, 1998 of ingevolge 'n wysiging (soos voorsien in artikel 34) van die Wet op die Bevordering van Gelykheid en die Verbod op Diskriminasie, 2000 beweer: nadat in 'n geding vasgestel is dat daar inderdaad differensiasie plaasgevind het, moet vasgestel word of die differensiasie op grond van MIV-status diskriminasie was, en indien wel, of die diskriminasie onbillik was. As die hof sou aanvaar dat die wetgewing MIV-status soos die ander gronde vermeld in artikel 9(3) van die Grondwet moet hanteer, word 'n weerleggingslas op die respondent geplaas waarvoor die Grondwet nie voorsiening maak nie, en sal die klaer van die bewyslas gekwyt word om aan te toon dat die differensiasie sy menswaardigheid aantas. Dit sou ooglopend neerkom op 'n implisiete wysiging deur gewone wetgewing van artikel 9 van die Grondwet.

Vir sover die uitbreiding dus neerkom op 'n wysiging (al sou dit bloot as 'n aanvulling beskou kan word) van artikel 9(2) van die Grondwet, is dit nie bestaanbaar nie, aangesien die Grondwet die hoogste reg is en nie by implikasie deur gewone parlementêre wetgewing gewysig kan word nie. So 'n aanvullende wysiging kan onder omstandighede besonder betekenisvol wees, aangesien geoorloofde differensiasie (waardeur menswaardigheid nie aangetas word nie) daardeur omskep kan word in onbillike diskriminasie.

\section{Gevolgtrekking}

Dit blyk dat die grondwetteks met ten minste drie konsepte wat met gelykheid verbind word, werk naamlik 'n waarde, spesifieke regte en 'n beskrywing van die soort samelewing wat nagestreef word. Daar kan geen twyfel bestaan oor die noodsaaklike rol wat die gelykheidsbegrip in die proses van die regstel van historiese wanbalanse moet vervul nie. ${ }^{45}$ Die beklemtoning egter van slegs die regstellende element van gelykheid veroorsaak dat daar konseptuele spanning ontstaan met die ander elemente van die begrip. Dit sou nie korrek wees om hierdie spanning net te verklaar aan die hand van die onderskeid tussen formele en substantiewe gelykheid nie, aangesien 'n wangebalanseerde beklemtoning van

45 "Particularly in a country such as South Africa, persons belonging to certain categories have suffered considerable unfair discrimination in the past. It is insufficient for the Constitution merely to ensure, through its Bill of Rights, that statutory provisions which have caused such unfair discrimination in the past are eliminated. Past unfair discrimination frequently has ongoing negative consequences, the continuation of which is not halted immediately when the initial causes thereof are eliminated, and unless remedied, may continue for a substantial time and even indefinitely. Like justice, equality delayed is equality denied" per Ackermann $\mathrm{r}$ in National Coalition for Gay and Lesbian Equality $v$ Minister of Justice 19991 SA 6 (KH) par [60]. 
regstelling ook wanbalanse teweeg sal bring in die uitkoms van gelykheidsaksies, dit wil sê binne die raamwerk van 'n substantiewe gelykheidstrewe.

Uit die ontleding van die huidige stand van die Suid-Afrikaanse gelykheidsreg blyk daar 'n neiging by sommige howe en skrywers te wees om gelykheidsbegrip te vereng tot die regstellende komponent daarvan. Dit word sterk bevorder deur die formulering van die gelykheidswetgewing. By die beleids- (en dus wets-)makers is 'n neiging te bespeur om maniere te vind om, in die najaging van die regstellende proses, op die bepalings van die Grondwet te probeer verbeter. Daardeur word soms veroorsaak dat vrae oor die regmatigheid van sulke maatreëls ontstaan. Daar word aan die hand gedoen dat die Grondwet voldoende voorsiening maar vir die regstellende proses terwyl die balans van 'n omvattende gelykheidsbegrip in die vorm van 'n kernwaarde van die Grondwet gehandhaaf word. Natuurlik moet die reg relevant vir die gemeenskap en die tyd wees, en derhalwe moet regstellende gelykheid nagejaag word, sonder egter om dat mode of heersende ideologie eensydige beklemtoning meebring wat elemente van ongelykheid in die gelykheidstrewe laat insypel. 'n Beperking van die grondwetlike gelykheidsbegrip, hetsy as waarde, kern van regte of as beskrywing van sosiale ideale, tot regstellende gelykheid sal 'n onregverdigbare verarming en dus gedeeltelike neutralisering van die grondwetteks meebring - dié les behoort uit die foute van positiwistiese regsvertolking van voorgrondwetlike tye geleer te word. 


\section{Bibliografie}

Carpenter 2002 THRHR 177-185

Carpenter G "Equality and non-discrimination in the new South African constitutional order: update (part 4)" 2002 (65) THRHR 177-185

Carpenter 2002 THRHR 37-58

Carpenter G "Equality and non-discrimination in the new South African constitutional order: the saga continues (part 3)" 2002 (65) THRHR 37-58

Carpenter 2001 THRHR 619-642

Carpenter G "Equality and non-discrimination in the new SA constitutional order: an important trilogy of decisions (part 2)" 2001 (64) THRHR 619-642

Carpenter 2001 THRHR 409-422

Carpenter G "Equality and non-discrimination in the new South African constitutional order: the early cases (part 1)" 2001 (64) THRHR 409-422

Cowen 2001 SAJHR

Cowen S "Can 'dignity' guide South Africa's equality jurisprudence?" 2001 (17) SAJHR 34

Davis 1999 SALJ

Davis D "Equality: the Majesty of Legoland Jurisprudence" 1999 (116) SALJ 398

Dupper 2002 SA Merc LJ 275

Dupper O "Affirmative Action and Substantive Equality: The South African

Experience" 2002 (14) SA Merc LJ 275

Dupper 2002 SA Merc LJ 221

Dupper O "Part-time Employees and the Pursuit of (Substantive) Equality: A

Comparative Study of the Potential and Limitations of Discrimination Law" 2002 SA

Merc LJ 221 
McGregor 2002 SA Merc LJ

McGregor M "Affirmative Action: An Account of the Case Law" 2002 SA Merc LJ

253

Rautenbach 2001 TSAR

Rautenbach IM "Die Konstitusionele Hof se Riglyne vir die Toepassing van die Reg op Gelykheid II" 2001 TSAR 329

Swanepoel "Equality Jurisprudence"

Swanepoel J "The Equality Jurisprudence Developed by South Africa's Constitutional

Court" in Pluralism and Law - Proceedings of the $20^{\text {th }}$ IVR World Congress

Amsterdam, 2001 (ARSP-Beiheft 88) 186-187

\section{Register van hofsake}

Brink v Kitshoff 19964 SA $197(\mathrm{KH})$

Dawood v Minister of Home Affairs 20003 SA 936 (KH)

Gauteng Provincial Legislature, Ep: In re Dispute Concerning the Constitutionality of

Certain Provisions of the Gauteng School Education Bill of 1995, 1996 (4) BCLR 537

Gauteng Provincial Legislature, Ep: In re Dispute Concerning the Constitutionality of

Certain Provisions of the Gauteng School Education Bill of 1995, 1996 (3) SA 165)

$(\mathrm{KH})$

Harksen $v$ Lane 19981 SA $300(\mathrm{KH})$

Larbi-Odam and Others v MEC for Education (North West Province) 19981 SA 745 (KH)

National Coalition for Gay and Lesbian Equality and Another v Minister of Justice and

Others 19991 SA $6(\mathrm{KH})$

Ntai v SA Breweries Ltd (2001) 22 ILJ 214 (AH)

President of the Republic of South Africa and Another v Hugo 19974 SA 1 (KH)

Pretoria City Council v Walker 19982 SA $363(\mathrm{KH})$

Prinsloo v Van der Linde 19973 SA 1012 (KH)

S v Makwanyane and Another 1995 (3) SA $391(\mathrm{KH})$

S v Makwanyane and Another 1995 (6) BCLR 665 


\section{Register van wetgewing en staatspublikasies}

Grondwet van die Republiek van Suid-Afrika 1996

GK R874 in SK 21517 van 1 September 2000

Wet op Billike Indiensneming 55 van 1998

Wet op die Bevordering van Gelykheid en die Voorkoming van Onbillike Diskriminasie 4 van 2000

Wet op Hoër Onderwys 101 van 1997 